Chapter 2

\title{
Cosmopolitans at Home: the Spanishness of Canadian Women Writers
}

\author{
Nieves Pascual
}

\section{Translation Theories and Cosmopolitanism}

In 1999, during the peak of institutional collaboration in the dissemination of Canadian writing in Spain, the Canadian Embassy, the Spanish Association for Canadian Studies and the prestigious Madrid cultural centre Círculo de Bellas Artes jointly organized a series of readings by Canadian Women Writers titled Escritoras canadienses de fin de siglo ("Canadian Women Writers of the Turn of the Century"). An invitation card was issued for each of the invited writers (Margaret Atwood, Mavis Gallant, Nicole Brossard, Ann-Marie MacDonald and Anne Michaels), for which several Spanish Canadianists were asked to write a text, while all featured a common blurb written by Bernd Dietz, professor of Canadian literature and founder of the Spanish Association for Canadian Studies (Fig. 2.1):

Dietz presented the cycle in his text ${ }^{53}$ in the following terms: "Can anybody still question that it is the time of Canadian women writers? At the moment, an attentive, enthusiastic and international reading public has succumbed to a singular constellation of narrative talent. Naturally, Spain is no exception and their novels regularly see the light in prestigious publishing houses." This text is symptomatic of the way English-Canadian literature has been presented in Spain: as an international, sophisticated, cosmopolitan, and "avant-garde" cultural artifact which is assimilated by the target or home culture, whose cosmopolitanism in turn enables reception of the newness of this foreign writing.

According to Homi K. Bhabha (1994), this newness enters the world through translation, a crucial and often neglected site for cultural production even if sometimes this "newness" goes unnoticed. This economy of entering spaces invites us to think of translation as a threshold, "the threshold of all readingwriting" (Derrida, 2004). Thresholds demand guardians and the guardian of translation must carry newness across (translate comes from the Latin trans+latus:

53 See a Spanish translation by Pilar Somacarrera in the Appendix 


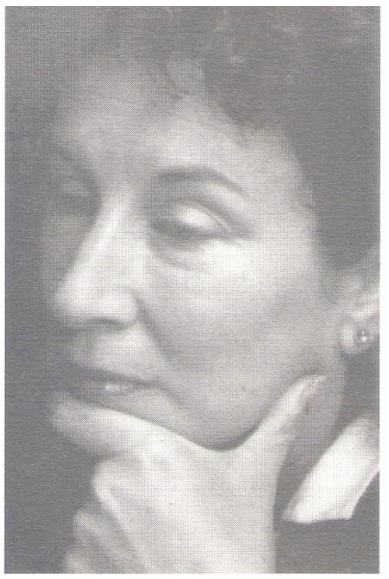

\section{MARGARET ATWOOD}

escritoras canadienses de fin de siglo

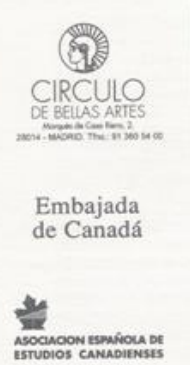

Alguién puede dudar aún de que es la hora de las narradoras canadienses? En la actualidad existe un público atento, entusiasta e internacional que se ha rendido ante una singular constolación de tolento narrativo. Naturalmente, España no es una excepción, por lo que sus novelas vienen apareciendo con regularidad en editoriales de prestigio. En 1999 además, visitarán nuestro pais algunas de las autoras canadienses de mayor rolieve. Pocos se atreverán a discutir el papel central de MARGARET ATWOOD, que habria brillado como poeta y ensayista de primer orden aun sin llegar a ser una de las novelistas más innovadoras e inteligentes de nuestro tiempo. Pero a su lado no palidecen los logros de una maestra del relato, y también novelista, como MAVIS GALLANI, que proyecta su identidad canadiense desde una perspectivo cosmopolita. Oe NICOLE BROSSARD, que junto a excelentes novelas experimentales ha tevalucionado lambién los campos de poesia y el ensayo. Oincluso de escritoras mas jovenes, como ANNe MiCHAELS y ANNMARt MACDONALD, que con sus novelas inaugurales han imumpido en la escont con enorme impacto.

Sus sorprenedentes trayectorias, con resultar deslumbrantes, son sólo la punta de lanza de Sus sorprenedentes trayectorias, con resultar destumbrantes, son solo considerable sobre la audacio de sus mujeres escritoras.

Bernd Dietz, Universidad de Córdobo

Fig. 2.1 Invitation card for Margaret Atwood at the Canadian Women Writers of the Turn of the Century reading series (February 16,1999 )

carried across). In physiology and psychology threshold can also mean the limit below which a stimulus is not perceptible or does not evoke a response (Barber, 2004). The translator's gaze must be capable of overreaching this limit, in the sense of possessing the ability, and, most importantly, the will to perceive.

Significantly, in Derrida's view translation is an act of generosity, or, in his words, "admiring love" (2004). In the understanding that love is both admiring - at least the erotic love that he has in mind - as well as responsible, Derrida (2004) writes about the translator's "beautiful and terrifying responsibility" and "his insolvent duty and debt." Since the word "responsibility" comes from responsum, which means "a reply" to the call of the Other, the duty of love is to respond to the Other's call to be transferred into the new culture. This is the 
beautiful part of the translator's responsibility. When Derrida (2004), alluding to Shakespeare's The Merchant of Venice, says that translation's debt is "Much like what is owed to Shylock, insolvency itself," he implies that the debt is insolvent because there are linguistic limits insurmountable by translation, and the translation between flesh and money is impossible. I am not interested in the hackneyed debate on the impossible possibility of translation. What matters to me is that Derrida's reference to Shylock the Jew exhibits translation as "stigmata of suffering" (2004). This is the terrifying part of the translator's work because what is at stake is the notion that translation foments violence, which takes the form of abuse, self-abnegation and abrasion of the bodies of text and translator alike.

Theorists of translation studies have often resorted to metaphors that connote this notion of violence. The concept of abuse, to start with, is the cornerstone of Lawrence Venuti's theory. In Rethinking Translation he demands that translation be dominated by "abusive fidelity" - fidelity to the tone of the source text and abusive of the literary norms of the target language - thereby allowing more elements of the foreign to enter the family of the target culture (Venuti, 1992). He calls upon translators to apply "resistant strategies" that evoke a sense of the foreign by sending the reader abroad instead of using domesticating ones (Venuti, 1992).

For Gayatri Spivak (2004), abuse gives way to self-abnegation as she confesses that during translation she surrenders to the control of the text, that is, she turns the self into something like the other and gives up her own self, "los[ing] [her] boundaries" in the process. A translation must have a sense of the rhetoricity of the original (Spivak, 2004). Logic moves from word to word, making clear connections but the translator must also attend to the rhetoric, which interrupts the process of making meaning, "breaking the surface in not necessarily connected ways" (Spivak, 2004).

Carol Maier in "Translation, Dépaysement, and Their Figuration" (2002) shifts the accent away from surrender into friction: "when translation occurs as fully as possible, the translator not only conveys or communicates a 'message' but may also experience the ambivalence, the absence of ease, and even the abrasion that are no doubt inherent in any dépaysement" or in any experience of exile. Translators must become "rootless cosmopolites" (Maier, 2002), implying that translators must free themselves from national attachments so as to be faithful to foreign cultures. Apparently, it is this rootless cosmopolitan commitment that provides the foundation of translation, as if cosmopolitanism were the very condition of translation. These three theoreticians hold that the process of translation is fully accomplished when translators separate themselves from their own pays, remove themselves from their home texts, and mentally estrange themselves from themselves by letting themselves be eroded by the abuse, abnegation and abrasiveness of the foreign. 
But, can one really uproot oneself? "Does the human self manifest any positive tendency in its structure, even an ambivalent one, to rise above its own worlds, its 'personalized space' to inhabit the other world?" asks Siby K. George (2010). Departing from a phenomenological vantage point, George, like Heidegger, leans toward the need of a sense of place. In this critic's view, our cultural proximities shape our notion of the self (George, 2010); but he combines this perspective, however, with the Lévinasian understanding of identity as porous and transcendent (versus solid and substantive), moving "from a world that is familiar to us ... toward a yonder" (George, 2010). It is precisely this movement towards this yonder place that challenges the at-homeness of the subject. George (2010) draws on Lévinas's idea of integrating the Other in the self when he suggests that to be oneself "is to be like a stranger, hunted down even in one's home, contested in one's own identity." "For Lévinas," George (2010) continues, "to be oneself is to be challenged by the other in one's very identity," to be foreign to oneself. The crucial point here is that when S.K. George (2004) says that "there is a way of 'living at home abroad or abroad at home"' and that "there certainly can be an at-homeness about not being at home anywhere," he means that rootedness and participation in the cosmopolitan ethos are not mutually exclusive. He adds that "it is always from the concrete [from what belongs to our immediate experience] that universality arises." (George, 2010).

The fundamental problem, however, is that S.K. George's theoretical stance is different from material reality, as he emphasizes himself: "Reality, however, is different: totality is a myth, the ultimate utopia which sustains the little and the non-central" (2010). The fact, as he acknowledges, is that the universal arises from the concrete but basically in the sense, I should add, that the concrete is being universalized; that is, the concrete familiar is being taken as the universal criterion of value. Judith Butler (2004) poses the following question: "At what cost do I establish the familiar as the criterion for valuing others?" The cost is universalism, the abstract cousin of cosmopolitanism (Anderson, 1999). Defined by Amanda Anderson (1999) as the project that holds that knowledge of the concrete is true and objective, universalism enacts "forms of privilege or exclusion" of ideas and aspects of other distant cultures that challenge that knowledge. This unavoidably results in a universalism that is not universal: "No true universalism can be constructed without recognizing that there is a diversity of universals on which analyses are based, and that these are often in fact quite particular -not universals at all, but rather interpretations devised for particular historical and conceptual situations. These are less universals, and more in the nature of arguments for the universal (Pollock et al., 2002). The non-universal character of universalism leads Sheldon Pollock et al. (2002) to propose "that cosmopolitanism be considered in the plural, as cosmopolitanisms." My title "Cosmopolitans at home" refers to the cosmopolitanism that is unchallenged by the foreign and affirms sameness. It refers to the cosmopolitan whose obligation 
to "a universal norm is tethered to a tenacious [...] provincialism in matters of cultural judgment and recognition" (Pollock et al., 2002). This universalist cosmopolitanism is violent too in the sense that it presupposes the dépaysement of the source culture, but I am running too far ahead of my argument.

My focus in this essay is not on the translated text itself, but on the paratexts that surround translation and which aim at disseminating the Canadian literary works of Margaret Laurence, Carol Shields, Elizabeth Smart, Mavis Gallant and Anne Michaels in Spain. Gérard Genette (1997) defines paratext as "what enables a text to become a book and to be offered as such to its readers. More than a boundary or a sealed border, the paratext is, rather, a threshold, - a word Borges used a propos of a preface- a 'vestibule' that offers the world at large the possibility of either stepping inside or turning back. ${ }^{\prime \prime 4}$ In other words, a paratext is the space where a textual product is public-ated. In the case at hand, the word "vestibule," which designates an anteroom, is more accurate than threshold, for the translated text is already a book when it is offered to its readers. Their decision to pass into the reading room once again depends on whether the paratext transfers the intensity of textual difference.

In examining these paratexts that make public the Canadian cultural product in Spain, I ask two questions: What is cosmopolitan in the Spanish literary field? How does a Canadian work become home in Spain? I will be drawing upon Bourdieu's work in answering these questions. The French sociologist defines symbolic capital as the degree of "prestige, celebrity, consecration or honour" a cultural artifact accumulates (quoted in Johnson, 1993), while he posits that cultural capital is the appreciation for or empathy towards other cultural products and "concerns forms of cultural knowledge, competences or dispositions." It is difficult not to read cultural capital in terms of the degree of cosmopolitanism an artifact accumulates. I will argue (a) that the symbolic capital of a Canadian literary work in Spain depends on the accumulation of cosmopolitanism; (b) that Canada is translated by and into Spanish culture as a cosmopolitan culture; and (c) that it is through cosmopolitanism that the work's specificity is denied and ours is confirmed.

First, in order to arrive at the essence of literary cosmopolitanism in Spain, I will examine the presses that publish texts by Canadian women writers by analyzing their editorial policies, which define the term cosmopolitan and produce reception patterns. Next, I will look at reviews by professional critics that appear in newspapers and on the internet, as well as jacket-blurbs. These will

$\mathbf{5 4}$ In his book Paratexts Genette also includes the literarys prize in the category of "factual" paratexts, but he leaves it unexamined and focuses on the "peritext" and "epitex," the features produced by the publisher and author of a text. 
more specifically affirm and consolidate legitimate discourse about Canadian cosmopolitanism. A final remark is appropriate on the complicated issue of the definition of terms. Having in mind the endless efforts to define cosmopolitanism and to differentiate cosmopolitanism, globalization, internationalism, pluralism, eclecticism, transversalism, and related terms from one another, and given their changing usage at different times and in different places, I have decided not to distinguish among them, but to take cosmopolitanism as a more comprehensive term including all the imaginable components belonging to the domain of the foreign.

\section{The Cosmopolitanism of Spanish Publishing Houses}

James H. Kavanagh (1990) writes that "the primary point of ideology, that which defines its social function, is not to 'give knowledge' or make an accurate 'copy' of something, but to constitute, adjust, and/or transform social subjects. The distinctive effect of ideology is not theoretical but pragmatic, to enable various social subjects to feel at home, and to act (or not act), within the limits of a given social project." If Kavanagh is correct and ideology makes one feel at home, then it is possible to speak of an ideology of cosmopolitanism. If the aim of ideology is not to abuse fidelity, but to cultivate fidelity to one's home, ideology certainly reveals affinities with the project of universalist cosmopolitanism defined above. Still, it is important to know which ideologies produce the feeling of home or, put differently, which ideologies produce cosmopolitanism? In this regard Kavanagh (1990) mentions literature and the framing discourses that "prepare and re-present texts, and associate them with other texts and social practices." Obviously he is referring to literary criticism and publishing houses. The latter he describes as apparatuses that prepare readers in their social context to receive a cultural message by working up "a rich 'system of representations' ... in specific material practices [read: texts]."

In the case of Canadian women writers in Spain, this preparation starts in 1969, when the Spanish publishing house Grijalbo begins to disseminate the Canadian message with the translation of Margaret Laurence's Rachel, Rachel. The publisher had been founded seven years before in Barcelona, where Juan Grijalbo had returned after his exile in Mexico. Although the message was launched in a vacuum, this translation had no bravura. In this case, as in many other cases of the translation of English-Canadian books in Spain, Bourdieu's insights hit the nail on the head when he affirms that "Translation is pre-eminently financial investment that always aims, openly or not, at the production of best-sellers" (1999). Two facts seemed to guarantee the commercial success of Laurence's 
novel in Spain. Firstly, Laurence had received the Governor General's Award for A Jest of God in 1966. Secondly, and perhaps, most importantly, Paul Newman had directed Rachel, Rachel, based on Laurence's novel, in 1968. Laurence's reputation was well-established when Grijalbo invested in the translation of her work. Although Grijalbo was absorbed by the Italian group Mondadori in 1989, no modifications were made in terms of the publishing policy of the imprint. Its official webpage reads: "In fiction, Grijalbo publishes best-sellers by first-rank names such as Barbara Wood or Ken Follett [...] as well as a renovated catalogue of international authors" mostly made up of works that have been successful in the United States.

Most tellingly, Bourdieu connects best-sellers with escape literature intended for or written by women. In his words: "The director of a series of foreign literature at a large publishing house identifies his best foreign breadwinners as 'great women's novels, escape novels,' especially those written in English. The more one approaches this pole, the more the publishers produce lucrative translations, resorting to the selection and purchasing processes of international speculation, massively introduced by scouts or American literary agents. One informant says that, even in France, 'the Americans are the masters."' (Bourdieu, 1999). In fact, when the evaluation criterion of internationalism is brought into alignment with best-selling fiction, it is, at the same time, bound to femininity and also, by implication, to youth. This is not surprising, since in Western culture women's writing has traditionally been considered immature and not serious enough to be taken into account, even if it appealed to large audiences.

The adjective "young", when applied to Canadian women writers and their works, carries connotations of freshness, vigor, vitality, and avant-gardism that can be extended to the press disseminating them. The avant-garde in its turn has a close affinity with eclecticism when one considers that experimentation is always composed of elements drawn from a variety of sources. It makes sense, then, that the first thing that leaps out when combing through the catalogue of Muchnik Editores is eclecticism. In 1994 Muchnik markets its translation of Laurence's A Jest of God/Una burla de Dios and A Bird in the House / Un pájaro en casa. It had already published a translation of The Fire-Dwellers/Los habitantes del fuego in 1993. In 1995 it issued The Diviners /El parque del desasosiego. In the course of 2003, Muchnik changed its name to El Aleph Editores, and the publisher continued to be steeped in an eclecticism that manifests itself in two ways: (1) through a selection of "foreign, Spanish and Latin American authors" and (2) through the "perfect synthesis of tradition and modernity," which is precisely how Margaret Laurence was marketed (webpage of El Aleph). One should note that the foreign excludes Latin American literature, which is supposed to make Spanish readers feel at home (as if Spanish literature did not stop at its borders), but includes Europe and North America. 
As to the past-present "synthesis," El Aleph specifies: "El Aleph basically publishes fiction, able to combine Nobel Prize winners like Elfriede Jelinek with the Portuguese avant-garde" (El Alpeh website). The "able," however, casts doubt on the possibility of such a combination. The publication of a Nobel Prize winner is undoubtedly an indication of commercial success, but is commercial success not in turn an index of traditionalism or non-eclecticism? The sad and sane truth of the matter is that, when a press accords priority to commercial aims, it also "perpetuates the most traditional literary forms or [canonizes] young authors conforming to old models or so uninformed of literary changes that they attach an idea of avant-gardism to the [...] house (Bourdieu, 1999). Bourdieu (1999) does not mention who these young authors are but he makes explicit reference to Gallimard and the consecration it has "given to several of the early discoveries (notably Samuel Beckett and Claude Simon)." In this manner old authors, like Beckett, Simon or like Margaret Laurence, for that matter, escape aging and the press is rejuvenated. The upshot of all this is that the publication of books that sell well goes hand in hand with the fantasy of modernity or conservative modernization conveyed by young authors who simply mime the real transgressions of the past or, in Bourdieu's words "produce attenuated or muted alternatives to the original ruptures" (1999).

This fantasy of modernity has endeared Tusquets Editores to a generally middleclass readership. Headquartered in Barcelona, Tusquets is a mid-sized publishing house with reduced salaried staff and branches in Mexico and Argentina. It started in 1968 with an insurgent ideological framework, proof of which is that 25 of its titles were censored during Franco's dictatorship. Today its founder Beatriz de Moura continues to rebel against the literary establishment when she describes her editorial philosophy as follows: "From the beginning I aimed at three targets: 1. Reclaim 20th-century vanguards and the literature which despite being marginal, minority and even 'damned' was still important; 2. Provide elements for a lively, active and polemic debate in the field of culture and ideas through texts against the granite ideologies dominant at the time; and 3. Publish the prose of novel Spanish and Latin American authors" (website of Tusquets). This does not mean that Tusquets does not publish foreign-language writers. Milan Kundera, Italo Calvino, Samuel Beckett, Albert Camus, William Faulkner, Henry James, Arthur Miller, Alexandr Solzhenitsyn, Edgar Allan Poe, Ezra Pound, Jonathan Swift, Mark Twain, Boris Vian, Nadine Gordimer and James Joyce, for instance, appear under their imprint. They also published such an emblematic title as Michael Ondaatje's In the Skin of a Lion/ En una piel de león. This translation was released in 1989, only two years after its original publication and almost six years before Ondaatje became popular, thanks to the adaptation of his novel The English Patient into film. The experimental and avant-garde nature of Ondaatje's novel would certainly suit the first two of the publisher's aforementioned objectives, although he can hardly be considered a "marginal" writer at the moment. 
In 1996 Tusquets published The Stone Diaries/La memoria de las piedras by Carol Shields. The translation of this novel came heralded by a range of literary prizes: it had won the Governor General's Award in 1993 and had been nominated for the Booker Prize the same year, followed by the National Book Award (1994) and the Pulitzer Prize in 1995. As an author with a double national affiliation (US and Canada ${ }^{55}$ ) and what Robert Thacker (2009) calls an "unassuming feminist commitment," she had the perfect cosmopolitan profile that the Spanish publisher needed. However, despite protestations to the contrary, Tusquets clearly favors the publication of the canonical - Shields is certainly considered part of the canon - painlessly entering the world of dominant ideology.

As Graham Huggan (2001) perceptively points out, the function of canons is to prop up "the institutional systems through which 'traditional' values are inculcated and upheld." Contrary to Guillory, who, in Cultural Capital (1993), associates the traditional values sustained by canonical works with the cultural élite, Huggan (2001) links them to the bourgeoisie. On discussing the canonical status of Margaret Atwood's work, he brings to the fore her antiestablishment views and remarks that these "have always tended to move with the fashions of the moment [...] [and deep down] represent the orthodoxy for [the] particular social group" of the middle-class. Her oppositional stance, translated into marginalized and disempowered heroines, is to Huggan (2001) a fantasy negotiated "from the safety of the middle-class family, the middleclass educational system, the middle-class home". What appears to be at the root of the paradox is that "her novels elicit sympathy not so much because they [her characters] are outsiders as because they register readily identifiable forms of middle-class alienation (Huggan, 2001), just as Shields' heroines. I would like to push the argument further by suggesting that this middle-class alienation makes Atwood and Shields compatible. In their novels we are involved in a bourgeoisization of alienation which compels the particular to explain an unfashionable universal. In other words, subversion is timeless and therefore eternally young, no matter that its writers are dead or aged, and, the timelessness of subversion is linked to an alienation discourse which, although grounded in the concrete existence of the middle-class, elicits universal sympathies. These characteristics can also be applied to the other Canadian writers I shall discuss below.

55 When Chicago-born Carol Shields, who had lived in Canada since 1957, visited Madrid in 1996 on the occasion of the launching of The Stone Diaries in Spanish, her trip was sponsored by the US Embassy. She gave her reading at the Instituto International, founded in 1871 - when Spain was far from being a cosmopolitan country-, as a charitable mission by an American couple, Alice and William Gulick, to promote the education of Spanish women. 
When I said that in Spain the foreign excludes Latin American literature, I meant that our imagination of home is closely linked to it. Now I wish to contend that, by virtue of canonization, the our of our literature is made even more inclusive. Let me expand on this argument by addressing the literary capital of two other publishing houses: Periférica and Sirmio (subsidiary of Acantilado). A brief word on Lumen is appropriate too. Lumen Editores is closely linked to Tusquets at the level of the distribution of published works. ${ }^{56}$ While it boasts of its autonomy as an imprint, it pursues the same publishing policy of illusive modernity as Tusquets. The banner on its web page reads: "Lumen bets on the classics of yesterday, today and tomorrow." In 1996 it commissioned the translation of Elizabeth Smart's By Grand Central Station I Sat Down and Wept from Laura Freixas, 57 renowned Spanish novelist, influential in the Spanish social context through her contributions to two newspapers of high circulation in the country like El País and La Vanguardia. She also translated By Heart/ Elizabeth Smart (1996), Rosemary Sullivan's biography of the author, reviewed by Lourdes Fernández-Ventura as yet another example of the bourgeois alienation which the Spanish literary system has found so attractive in Canadian women writers: "Elizabeth Smart had a paradoxical life: she escaped from her destiny as a beautiful debutante from the Ottawa high bourgeoisie, and persisted in an illegitimate passion (Ventura, 1996).

More than ten years later (2009) By Grand Central Station I Sat Down and Wept was reissued by Periférica, a small publisher set in Cáceres ${ }^{58}$. Established in 2006, Periférica offers through its 42 published titles a selection of "modern classics." It is worth noting that the selection includes mostly consecrated writers who helped create the idea of Europe, and that the press won the National Prize for Cultural Editorial Work in 2008. However, the editorial trend which must have led them to reprint Elizabeth Smart's prose poem is, as published on their web page, that they intend to leave some room to recover titles that emerged in the

56 The story of their association, however, contains a family plot. In 1960 Magín Tusquets bought Lumen, a publishing house specialized in religious books founded during the Spanish Civil War, from his brother Juan Tusquets, a supporter of Franco's side. Soon after that, his daughter Esther Tusquets took over as director, helped by her brother Oscar. In 1969 Oscar Tusquets and his wife, Beatriz de Moura, split from the original family business and created Tusquets Editores, while Esther continued to be the director of Lumen until 2001, when it had already been absorbed by the editorial group Bertelsman.

$\mathbf{5 7}$ In the same year, 1996, Laura Freixas had also translated Rosemary Sullivan's biography of Elizabeth Smart By Heart for publisher Circe, which specialized in books written by and about women.

58 Cáceres is the second largest city in the autonomous region of Extremadura which, before the upsurge of the autonomous communities in Spain, was traditionally known as an impoverished region whose population was drained by emigration to other, more prosperous regions of Spain, like Catalonia. 
twentieth century on the margins of the "literary establishment" or the dominant taste, and which represent "a submerged current of contemporary literature." 59 If we read through the lens of the polysystems theory, Smart's book was chosen because the prose poem is a literary genre lacking in the Spanish literary system. However, the reviews published in the Spanish press for the occasion of the reediting of the book describe it as an autobiographical account of a passionate and obsessive love story. The titles of the articles are revealing in themselves: Hidalgo, "Elizabeth Smart: arte, amor, hijos/ art, love, children" (Hidalgo, 2009), and "Crónica de un amor obsesivo"/"Chronicle of an obsessive love," (Aparicio Maydeu, 2009).

Despite its prize for cultural editorial work, Periférica does not have the cosmopolitan glamour of Lumen, which celebrated its fiftieth anniversary in 2010, and, according to its web page has always aimed to look for authors who are strong enough to become classics" and has published women authors like Antonia Byatt, Linn Ullmann and Alice Munro. In 2009 Lumen published Mavis Gallant's The Selected Stories/Los cuentos, once the reputation of Canadian writers of short stories was established in Spain, including the following blurb, attributed to the editor, on the dust jacket of the book: "Flannery O'Connor, Eudora Welty, Natalia Ginzburg and now Mavis Gallant. These ladies of writing are the pride of Lumen's catalogue" (Gallant, 2009, dust jacket). However, before Mavis Gallant had become "a lady of writing" in Spain, it was the publisher Sirmio that introduced her work with the translations of Overhead in a Balloon, published in the same volume as Paris Notebooks, in 1990 (Elevado en un globo/Doce historias de Paris) and In Transit/ En tránsito in 1992. Sirmio was created in 1987 as a Spanish-language imprint of Quaderns Crema, a Catalan publishing house founded by Jaume Vallcorba, at the time professor of Spanish literature at the University of Barcelona. As Josep Maria Ripoll (1990) observes in his review of the Spanish translation of Overhead in Balloon, Sirmio specialized in "little oddities of the connoisseur which had been forgotten...or renowned authors who were unpublished among us, such as the case of Mavis Gallant." In Jaume Vallocarba's words, the press capitalizes on "transversal thinking" in place and time, that is, a combination of the classical and the modern, "moving outside fashions in a subtle balance between the intellectual and the commercial." 60 Significantly, Vallcorba exerts great influence on the

59 See the website of Periférica. Periférica has recently published the second part of Smart's autobiography, The Assumption of the Rogues and the Rascals / Los pícaros y los canallas van al cielo (2011).

60 See the web page of his current publishing house Acantilado, founded in 1999. Acantilado means "cliff" and Vallcorba acknowledges giving it this title to refer to the risks of starting such a press of such characteristics. 
awarding of literary prizes and has received many prizes himself: "In 2002, Jaume Vallcorba receives the National Prize for best editorial work awarded by the Spanish Ministry of Culture, and soon after the Gold Medal of Cultural Merit by Barcelona Town Hall as well as the Great Order of Cultural Merit of the Republic of Poland, granted as recognition for the projection of Polish literature to the Hispanic world" (http://www.acantilado.es/). The honours received by Vallcorba speak to a certain Europeanization of the press that makes his proposition of transversalism suspect. If national prizes are awarded as recognition for publicizing European works, could we not say that the press is vernacularising Europe and, perhaps more importantly, concomitantly provincializing the canonical? What is clear is that for Sirmio, Lumen, and Periférica the canonical enables us to feel at home. It is also clear that, for these publishers, the canonical is European but includes Canadian Literature, as if Europe subsumes Canada.

This Europeanizing strategy becomes more nuanced in the "global project" of Alfaguara, yet another Spanish publisher. Founded in 1964 by Nobel Prize winner Camilo José Cela, Alfaguara has 20 offices in various American countries and reaches "more than 400 million readers" (Alfaguara website). The publisher organizes the Premio Alfaguara de Novela, "a referent of quality literary prizes awarded to an unpublished work written in Spanish," and boasts of a "global vocation, Latin American and Spanish." At first sight, the "global" reach of this publisher solely embraces Latin America and Spain. This impression is confirmed through the description of the project "Alfaguara Global":

The Project Alfaguara Global [...] originates in 1993 with the publication of Cuando ya no importe by Juan Carlos Onetti, one of the emblematic authors of Latin American literature in our century. This edition, the outcome of the joint efforts of the Alfaguara editors from both sides of the Atlantic, has opened the path to follow. Since then, we have continued to publish Spanish and Latin American writers, both from the boom period and from the new generations, in a permanent back-and-forth journey from Spain to America, which makes the global vocation of Alfaguara more meaningful (Alfaguara website).

Clearly Spanish and Latin American literature alone are here made into the sign of Alfaguara's global vocation. Undoubtedly, the symbolic capital of the publisher is established by way of its purported global vocation, but also involves its access to national award juries, the institutionalization, circulation and impact of its prize, as well as the prestige of its list of published works. It should be stressed that Alfaguara translated in 1997 Anne Michaels' Fugitive Pieces as Piezas en fuga by Alfaguara. Fugitive Pieces was reprinted in 2008, and 
in 2010 they issued her book The Winter Vault/La cripta de invierno. ${ }^{61}$ The call of its uniquely "global" vocation may have been ignored when they published Michaels' first novel due to the many prizes it had garnered (The Orange Prize for Fiction, the Trillium Book Award, the Chapters/Books in Canada First Novel Award and a Lannan Literary Award for Fiction). Another more plausible interpretation, however, is that under the banner of the global, situated in the intimate sphere of Spain and Latin America, the publisher crusades for a host of internationally recognized award-winning texts which become intimate by losing their own situatedness. We will see that, in effect, Canada is merely glossed over in literary reviews, neither explained nor situated. Of course, there is much violence in this dépaysement against the Other (the Canadian Other in this case), who is forced to lose her boundary in order to turn into something like the self.

In order to explain the publishing policy of yet another publishing house, Bartleby, I need to elaborate on what Alfaguara means by its "global vocation." The word "vocation" comes from the Latin vocare, meaning "to call" and situates the global in the field of responsibility. Implied is the duty to respond to the call of others stemming not - as seen - from our difference from them but from their sameness to us. "Vocation" also brings to mind associations of virtue (a vocation is a response to a divine, religious call) and remuneration (a vocation is a profession or a job), the combination of which is a prevalent strategy in the publishing world, or rather, it is the duty of publishers. "Publishers," writes Bourdieu (1999), "are thus double characters who should know how to reconcile art and money, the love of literature and the quest for profit. Their strategies must be located somewhere between realistic or cynical submittal to commercial considerations, and heroic or foolish indifference to financial needs." 62

Bartleby is a very small independent publisher that distributed Michaels's The Weight of Oranges/El peso de las naranjas and Miners Pond in 2001,63 followed two years later by Skin Divers/ Buceadores de la piel. To Pepo Paz, editor-in-chief of Bartleby, independence is the attribute of a press like his that does not participate in the race for literary prizes, does not cultivate institutional contacts or recommendations, does not compete for best-sellers,

61 Both books were translated by Eva Cruz, daughter to Juan Cruz, direction assistant of El País. El País and Alfaguara are brands of the business group PRISA, which explains the attention the Spanish newspaper often pays to Alfaguara's publications.

62 Bourdieu, "A Conservative Revolution in French Publishing."

63 The 2003 edition of Skin Divers published by Barteby is prefaced by writer Alfonso Armada, renowned journalist and regular contributor to El País. The epilogue is written by poet Jordi Doce, who has translated Paul Auster, William Blake and T.S.Eliot,among others, into Spanish. Undoubtedly, this confers a high symbolic value on the text. The text is monolingual (only Spanish). 
is willing to take risks with "new" and "unknown" authors, and specializes in "a plural literature" (El lector perdido, blog, 2009) It is clear that cosmopolitanism supports Paz's insistence on "independence," but this insistence does not mark his freedom from dependence on the processes of power. Bourdieu (1999) explains that the constraints imposed on small publishers make their margin for maneuvering very narrow, although these publishers help "provide the game with its basic justification and 'spiritual point of honor,"' meaning that, because they do not have the means to enter the race (of prices, publicity, contacts and big international best-sellers), they are forced to become virtuous by espousing an independence and/or cosmopolitanism that are actually forced upon them (1999).

Significantly, however, much as Paz discredits the publishers' race, he at once confesses his desire to address the "largest possible public." This is essentially an open confession of a profit-driven desire that ultimately reveals his virtuous global vocation to be a commercial ruse. Although no press, no matter how lofty its ideals, can afford not to be profit-driven, all this indicates that cosmopolitanism is the euphemism for the "sordidly commercial" (Bourdieu, 1999) maneuvers of the editorial world. On how the material conditions that rule the selling of books are euphemized, again Bourdieu (1993) has this to say: "Entering the field of literature is not much like going into religion as getting into a select club: the publisher is one of those prestigious sponsors (together with prefacewriters and critics) who effusively recommend the candidate [...]. But the law of the universe, whereby the less visible the investment, the more productive it is symbolically, means that promotion exercises, which in the business world take the overt form of publicity, must here be euphemized.The implication is that, first, the more "spiritual" a publisher becomes, the more material profit it accumulates, and, second, that the material has to be euphemized as spiritual in order to be profitable. On another level, I wonder what the difference is between going into religion and getting into a select club when we consider the euphemism hidden within "vocation," religious or otherwise. Perhaps instead of the ideology of cosmopolitanism, it would be more accurate to speak of the ideology of the cosmopolitan vocation as that which enables social subjects to feel at home for purposes of solid profit.

\section{Cosmopolitanizing Strategies}

The rest of this essay focuses on the strategies used to disseminate Canadian literature in Spain. The use of the word "strategy" is inspired by Venuti's Rethinking Translation and determined by the business connotations it carries. I begin with the basic idea that Canadian literature is translated as a cosmopolitan literature and show that cosmopolitanism, as it may already 
be apparent, is one of the primary conceits for illustrating Canadian nondifference, so that, far from being "resistant," it operates as a "domesticating" strategy. Cosmopolitanizing strategies include: (1) emphasis on vitality and tradition (European and American), which I have called the fantasy of modernity; (2) attention to bourgeois alienation; and (3) use of an international style. The first two strategies have already been discussed in the first two sections of this essay.

In order to address the first cosmopolitanizing strategy I need to return to the text of the brochure of the cycle "Canadian Women Writers of the Turn of the Century" mentioned at the beginning of this chapter. Clearly the title of the reading series is intended to ring associations of experimentation. Inevitably, "turn of the century" connotes a change and therefore a break with tradition. This is precisely what Bernd Dietz underscores when he asks: "Can anybody still question that it is the time of Canadian women writers?"64? He then describes the potential readership of these writers as "attentive, enthusiastic and international," adding that that this "singular constellation of narrative talent" could, obviously, not escape Spanish readers and publishers. Canadian women writers, he points out, are only "the spearhead of a young already powerful literature" which rests on their "audacity." I will not focus here on the connection between internationalism and mainstream publishers or their affinities with youthfulness, femininity, and the avant-garde, as this has already been discussed. It needs be stressed, however, that the youthfulness of this "powerful" literature circulates here as a token of symbolic capital. The economy of transmission between reader and text implicit in Dietz's words suggests that this capital is indeed translated, not from texts to readers, as might be expected, but to texts from readers, who are already attentive, enthusiastic and international when they enter the intimate scene of Canadian women's writing. What is more, the sum of these qualities enables them to embrace this "singular" constellation, singular because their readers are preeminently singular. It is mostly in them and not in the text that singularity resides. With this move Dietz accomplishes two things. On the one hand, he includes us in the Canadian literary system by making it feel like our own projection. On the other hand, he consecrates our reading competence and hence the literature (read: the canon) that has made its acquisition possible.

In "Soledades y desamores"/"Loneliness and Unrequited Loves," a review of Margaret Laurence's The Diviners, Valentí Puig (1995) capitalizes on the relation between the young and the canonical, juggling the former's need for autonomy with the latter's desire for relatedness:

64 See full text of the brochure in the Appendix. 
The prestige of Margaret Laurence is not just due to the efforts of young literatures to copy the elements of an adult literature: its wise men, its rebels, its Victor Hugo and its Kafka; and its great woman writer. In the case of Canada there had to be a great writer of the prairie and such a writer was Margaret Laurence. In the national Canadian literature studied at school, Margaret Laurence's books occupy an outstanding position in the syllabus, so that the children of the Canadian melting pot may know the streets of Manawaka, with the Tabernacle, the Parthenon bar, the Flamingo Club, the Roxy Theater and the jokes of Ukrainian children.

Whether Laurence is Canada's great woman writer is debatable although several Spanish critics seem to agree that she is, even greater than Atwood. ${ }^{65}$ The question is, of course, whether the geographical specificities mentioned can provide Canadian literature with the originality that is not a copy of the "adult literature" Puig mentions in his review. The short answer is probably yes, but when the author concludes by saying that "the honesty and sincerity [of] Margaret Laurence brings proximity" to contexts that otherwise would feel foreign, he pointedly gives us to understand that the cultural capital she accumulates here results from empathy towards our old literary geographies (our Victor Hugo and our Kafka and hence our Margaret Laurence) rather than from the appreciation for distant ones (their Victor Hugo and their Kafka and their Laurence).

In his review of Anne Michael's Fugitive Pieces for the Argentinian newspaper La Nación, which provides evidence of Alfaguara's global outreach, Eduardo Berti (2011) demonstrates his knowledge of this matter when he recalls that Jakob Beer and Athos Roussos settle in Toronto, but nothing more is said of the locale. Why is nothing said if not to make the site imprecise, intangible, unidentified and unmemorable? Poland, however, brings to his mind memories of the war and serves as a stepping stone to other data such as Michaels' place of birth. This is a recurrent strategy of Spanish commentators who often hasten to make a point about the European origins of Canadian novelists and are prone to narrate their experiences in Europe. Greece inspires in Berti (2011) a whole ode: "The inclusion of Greece as the third country in the novel [the other two being Canada and Poland] is not casual. Zakynthos is an island where great poets are born; Greece is the cradle of poetry and European cultures." Echoes of Greek poetry, however, do not resonate in Michaels's novel but echoes of our Paul Celan and our Adorno do, as Berti makes clear. For her part,

65 Ayala-Dip (1993) in his review of The Fire-Dwellers argues that Laurence is subtler and richer in psychological nuances than her countrywoman Margaret Atwood. 
the Spanish academic critic Esther Sánchez-Pardo also recognizes in Fugitive Pieces the voices of Walter Benjamin and Primo Levi. ${ }^{66}$ Muñoz Molina in El País investigates the stylistic features of The Winter Vault by relating it to the work of Proust and Juan Carlos Onetti. Celia Ramis discovers Borges and Whitman in The Weight of Oranges.

The same strategy of alluding to canonical writers is applied to the other writers who are being addressed in this chapter. Reviewer María José Obiol (1996a) remembers that Elizabeth Smart lived by the maxim of Kafka who said that literature works like a pickaxe to break the frozen seas inside the soul. In the review "Jardines fascinantes" by Tomàs Delclós (2008), Carol Shields is listed alongside the names of Borges and Goethe. In the invitation card for Mavis Gallant's lecture, Pilar Somacarrera describes Mavis Gallant's work through references to the novels of Jane Austen and the short stories of Anton Chekhov. ${ }^{67}$ The comparison gains additional significance in the light of "Destellos deslumbrantes," ("Blinding twinkles"- the title seems to anticipate Dietz's star imagery as deployed in the text of the Canadian Women Writers cycle) wherein Jorge Barriuso (1993) opines that In Transit "sometimes reminds us of a certain Joyce, and at other times, of a certain Chekhov." Chekhov is again alluded to by Josep Maria Ripoll (1990) Julià Guillamon (1990b) in her review titled "Eventualidad" adds Henry James and F. Scott Fitzgerald to the catalogue of correlatives. In her review of Mavis Gallant's Selected Stories, writer and journalist Rosa Montero (2010) confesses having felt the same emotions reading Gallant and Steinbeck. Perceptively, Salustiano Martín (1993) asks: "To what extent is Mavis Gallant a Canadian writer?" Put at its simplest, Gallant appears not singularly different from Joyce, Chekhov, Austen or James, which begs the difficult question of whether the canonical writers she is compared to are singularly different among themselves. There is a clear reason for these comparisons with canonical writers: by approximating Canadian authors to the European canon, Spanish reviewers "own" the works.

Nevertheless, I have already explained that canons combine modernity and tradition, or, to be more precise, offer tradition under the guise of modernity. Definitively, Kafka, Celan, Adorno, Levi, Benjamin, Goethe, Proust, Whitman,

66 In the brochure card dedicated to Anne Michaels for "Canadian Women Writers of the Turn of the Century."

67 Once again, in the invitation card for Mavis Gallant issued for "Canadian Women Writers of the Turn of the Century" referred to in the main text. Gallant has another "domestic" connection to Spain. As Pilar Somacarrera explains in her text, her presence in the cycle meant her return to Spain fifty years after her visit (1951), which had inspired her two stories about life in Madrid in the 1950s. Ironically, Gallant cancelled her visit in the last minute due to unexpected health problems. Now in her late eighties, it is doubtful that she will ever resume that journey. 
James, Austen, Fitzgerald, Chekhov and Joyce fit the canonical fantasy of conservative modernization. I would argue that Canadian literature, when taken over by these canonical writers, becomes young and old, modern and classic simultaneously. In light of this, if one cannot doubt that it is the time of Canadian women writers, one cannot doubt either that it will remain so as long as they add to our intimate estate of literary capital.

In order to explain the second cosmopolitanizing strategy, which I have called "attention to bourgeois alienation," I need to go back to Huggan's argument that Atwood's subversive views are negotiated through "identifiable" and tranquillizing "forms of middle-class alienation" (2001) — which implies no subversion at all and then apply it to Elizabeth Smart. Following Huggan (2001), Atwood's "success is largely due to her ability to capture and mobilize popular feelings." It is crucial to note here that middle-class alienation is popular as it is easy to understand for the majority as well as the minority. The forms this alienation takes he does not specify. What follows is my own brief description of these forms of alienation present in Spanish reviews of Elizabeth Smart's By Grand Central Station I Sat Down and Wept. Consider the following: "By Grand Central Station I Sat Down and Wept is more than the narrative of a passion, most of all it is the testimony of the pain that sticks to the feeling of love," writes Obiol (1996). Unrequited love is one form. Illicit love is another. A brief blurb titled "Canción triste de Elizabeth Smart"/"Elizabeth Smart's Blues") inserted in the book section of the women's magazine (Mujer hoy) published jointly with the national newspaper $A B C$, announces the following about the second part of Smart's autobiography, The Assumption of the Rogues and the Rascals, published by Periférica: "Last year Periférica moved us with By Grand Central Station I Sat Down and Wept, the romance of writer Elizabeth Smart with the married (not to her) poet George Barker in the thirties. It has now published its sequel, whose beginning is heartbreaking."

J. Ernesto Ayala-Dip, a regular collaborator to Babelia, refers to the liberalizing contradiction Laurence creates in one of her heroines: "Stancey [sic] [in The Diviners], on the verge of forty, must preserve the tenderness she feels for her husband from herself, from her own destructive impulse. This crossroads frees her from the boredom of marriage and launches her into the arms of a man younger than her" (1993). Old age is one more source of estrangement in the world and from the self, as José Antonio Gurpegui (1994) makes clear in his review of The Stone Angel/El angel de piedra, where he explores 90-year-old Hagar Shipley's sense of existence. It may also be observed that the dislocation of travelling and the loneliness grounded in everyday life appear indispensable ingredients of alienation in Mavis Gallant's works. The other two big forms alienation takes are the pain of loss, in the case of Shields, and the suffering that results from inherited memories. About Anne Michaels' Fugitive Pieces, Elsa Fernández-Santos (1997) writes: "Jakob and Ben are marked by events that did not happen to them, and this is a reality to all of us." Similarly, the memory 
of what has not been lived and the pain that clings to it also shapes Andrea Aguilar's interview of Michaels in El País (2010).

These forms of alienation are real to all of us because they are neither abstract nor philosophical, attributes that would make them difficult to assimilate. They are not materialistic either. Another way to put this is to say that the economic system does not spawn and sustain them because this might make them threatening. Rather, these forms are material or concerned with what is emotionally experienced: "The goal of Michaels," writes Fernández-Santos (1997), is "to communicate sentiments." More specifically, the examined reviews find a form of connection in alienation. The writers' appeal to connection plunges us into the assumption -however highly contestable- that emotions are natural and universal, not subject to referential (class) restraints and transferable from one person. It makes sense, logically, that Salustiano Martín (1993) speaks of "the absence of rooted sentimentality" when he describes In Transit. It is not my business here to discuss the cultural constructedness of emotion. What is important for my purpose is that these reviews are over-determined by the belief that emotions of alienation are translatable and universal (in much the same manner as the concrete is universalized) and that this makes them tranquillizing for readers and reviewers alike.

The immediate prompt to the idea that emotions are translatable is the fact that words transmit emotions. Zoltán Kövecses (2000) asserts, if not insists, that language creates emotional realities. For her part, Teresa Brennan (2004) goes further when she claims that one can catch an emotion from the physical properties of words. Obviously, this argument is correct. The art of poetry would not exist were it not for the rhythm, sound, tone, pitch, stress, melody, vibration and pace of the words that make up a poem. If we accept this argument we also have to accept that a certain style may transmit a certain affect and that emotions of alienation are translatable because they are carried in what Julià Guillamon (1990a) in her review of Gallant's Overhead in a Balloon and Paris Notebooks calls "International Style," which is the name I have suggested for the third cosmpolitanizing strategy used for Canadian women writers in Spain. Guillamon (1990) writes: "Still effective is the civility of the international style of this writer, in whose descriptions nothing is accessory, and in which people and things are subtly woven into the story's texture and structure." The international style is linked to precision in descriptions, lack of verbosity, absence of extraneous elements in the structure and "superb realism." Myrta Sessarego (1993) emphasizes Gallant's "clean realism," which she associates with "elegant precisions and meticulous details," "removal of superficial and rhetorical makeup" and "hard lyricism."

Much in tune with the previous tenor of description is Cecilia Ramis's tenet of transparency: Michaels's "language names the real to make it recognizable" (2001). Ayala-Dip's critical approach to Laurence's The Fire-Dwellers occurs in 
the expressions: "tranche de vie," "authentic literary relevance," "old narrative method," and "structural unity" (1993), which means there is a beginning, middle, end, and central theme. Of Shields's Unless, Rosa Regàs (1997) praises its "naturalness," that is, "the solid structure" and "impeccability" of her prose. The back-cover reads: "Unless is a brilliant, daring novel that has the mastery of extraordinary works about the so-called 'normal people."' Briefly put, social realism is international because it casts off the artificial and the opaque. But how can this preference for the mode of social realism be explained? The reason is that although the world portrayed is imaginary, realism attaches us to the real world and thus the orderly character of the narration allows us to order our lived experience. "Progressive realism," as Spivak (2004) puts it, "is a charismatic way of writing prize-winning fiction [...]. Progressive realism is the too-easy accessibility of translation as transfer of substance;" it makes translation accessible and easy insomuch as it brings the foreign text to readers on their own terms, pleasurably.

\section{Conclusions}

In What Is Translation? Douglas Robinson (1997) criticizes Venuti's concept of "abusive fidelity" in the following terms: "[I]n an abusive translation... who is the abused? The source language author, text, culture? The target language reader, text, culture? Both, or in some combination of the various aspects of the two? [...] What social and psychological effects does it have on its victims and its perpetrators?" Venuti (1998) proposes that the abuse be committed against the hegemonic norms of the target culture through foreignizing strategies. Yet, these strategies, Robinson argues, also abuse source authors and may be unfair to them as well, especially when they cannot fight back, which is usually the case. In like manner, the cosmopolitanizing strategies that foreground the familiar by domesticating the different are abusive of the target culture too, because by hindering the entrance of newness they condemn us to a sameness that impedes conscious awareness of selfhood, which, in accordance with Lévinas, needs to be challenged by the Other. In this logic, if abuse is the measure of responsibility in translation, both kinds of strategies - foreignizing and domesticating - are equally responsible for the violence exerted in the transference process. Thus, one question emerges: is mediation between cultures only possible via abuse? Or, in other words, are cultural thresholds always sites of violence?

The aim of this chapter has been to explore the dissemination of the works of Canadian women writers in Spain. Since the early times, when Canadian institutional agents were still not taking part, the transference of CanLit into the Spanish literary system has been dominated by commercial constraints. Margaret Laurence's Rachel, Rachel was imported by Grijalbo and later reprinted by Bruguera as a potential best-seller, based on the "great film directed by 
Paul Newman featuring Joanne Woodward" (Laurence, 1972, back cover). It could also have attracted publisher Grijalbo (and later Bruguera) because of its transgressive (certainly under Franco's regime) content about the sexual awakening of a formerly repressed schoolteacher. Other Spanish publishers like Tusquets allegedly import certain foreign writers -including Canadian authors like Carol Shields and Michael Ondaatje- because of their avant-guard and marginal nature, when they are in fact looking for internationally recognized and prize-winning texts. Therefore, the preference for modern and marginal writing just remains an illusion, what I have called the fantasy of modernity.

The Spanish literary system has received some of these Canadian women writers as if they had been writing from within a void, deleting any trace of a Canadian literary tradition. Following the first of the cosmpolitanizing strategies I have discussed in this chapter, Mavis Gallant and Anne Michaels are read in light of the European tradition of Chekhov, Joyce, Primo Levi or Adorno. These canonical correlates allow publishers and reviewers alike to feel at home, evading the abrasiveness of the Canadian foreign. The second strategy, dealing with bourgeois alienation, has been very productive in the transference of texts as distant from the Spanish literary tradition as Elizabeth Smart's memoirs. As an avant-garde woman writer and a single mother, who was passionately in love with a married man and endured much hardship in postwar England, Smart elicits the sympathies of many Spanish readers, male and female alike, who delusively think that the author's emotions are universal.

In Spain we have abused Canadian literature by making it recognizable. Making it unrecognizable would have abused its authors. Perhaps we need to put into practice Lévinas's and S.K. George's ideas and affirm the Other by affirming the self. This might start to be possible when responsibility is detached from abuse and love is dissociated from violence. 